\title{
The Bacillus stearothermophilus NUB36 surA gene encodes a thermophilic sucrase related to Bacillus subtilis SacA
}

\author{
Yang Li and Thomas Ferenci \\ Author for correspondence: Thomas Ferenci. Tel: +612351 4277. Fax: +6123514571. \\ e-mail: reeves02@angis.su.oz.au
}

Department of Microbiology G08, University of Sydney, Sydney, New South Wales 2006, Australia

\begin{abstract}
The complete nucleotide sequence of the surA gene, encoding a sucrase from Bacillus stearothermophilus NUB36, was determined. surA was composed of $1338 \mathrm{bp}$ and encoded 445 amino acid residues. The deduced polypeptide of $M_{\mathrm{r}}$ 51519 showed strong sequence similarity to sucrose and sucrose phosphate hydrolases from Bacillus subtilis, Klebsiella pneumoniae and Vibrio alginolyticus, and contained the 'sucrose box' residues thought to be important for catalysis of the transfer of fructose from sucrose. The enzyme was partially purified using affinity chromotography from extracts of Escherichia coli containing the cloned surA. SurA displayed an optimum temperature for sucrose hydrolysis of $55^{\circ} \mathrm{C}$ and high stability. The $M_{r}$ of SurA determined by gel filtration was 105000 , which suggested that the active form of the enzyme is a dimer. SurA exhibited an apparent $K_{m}$ of $\mathbf{4 0} \mathrm{mM}$ for sucrose but, unlike the homologous $B$. subtilis enzyme, had no detectable sucrose phosphate hydrolase activity.
\end{abstract}

Keywords: invertase, sucrose utilization, sucrose-phosphate hydrolase, Bacillus stearothermophilus

\section{INTRODUCTION}

Little is known about the genetics of sucrose metabolism in Bacillus stearothermophilus. In contrast, bacterial sucrose metabolism has been intensively studied in Bacillus subtilis (Lepesant, 1976; Fouet et al., 1986), Streptococcus mutans (St Martin \& Wittenberger, 1979; Robeson et al., 1983; Russell et al., 1985; Lunsford \& Macrina, 1986), and Escherichia coli harbouring the conjugative sucroseplasmid pUR 400, which was originally isolated in Salmonella typhimurium (Schmid et al., 1982, 1988; Ebner \& Lengeler, 1988). In all the above-studied organisms, sucrose is transported through the cell membrane via the phosphoenolpyruvate-dependent phosphotransferase system (PTS) and phosphorylated into sucrose 6-phosphate which is then cleaved by a sucrose-6-phosphate hydrolase yielding glucose 6-phosphate and fructose as cleavage products. Nucleotide sequences of sucrose hydrolase genes have been reported for B. subtilis (Fouet et al., 1986), Vibrio alginolyticus (Scholle et al., 1989), Strep. mutans (Sato \& Kuramitsu, 1988), Zymomonas mobilis (Gunasekaran et $a l ., 1990)$, and the pUR400-encoded system from $S$.

The GenBank accession number for the sequence reported in this paper is U34872. typhimurium (Schmid et al., 1988). The deduced amino acid sequences of these enzymes show strong homology, especially in several conserved regions suggested to be important in the transfer of fructose from sucrose.

Here we present the nucleotide sequence of the $B$. stearotbermopbilus NUB36 sur $A$ gene (1338 bp), which encodes a thermostable sucrase (SurA). Comparison of the deduced amino acid sequence of $\operatorname{sur} A$ with the sucrose hydrolases of B. subtilis (sucrose-6-phosphate hydrolase), Klebsiella pneumoniae (sucrose-6-phosphate hydrolase) and $V$. alginolyticus (sucrase) revealed strong homology in the putative enzymically functional regions. High expression of the gene was achieved in $E$. coli, which permitted partial purification of the enzyme and characterization of its activity.

\section{METHODS}

Bacterial strains, plasmids, and culture conditions. B. stearothermophilus NUB36 was the source of chromosomal DNA (Welker, 1978; Chen et al., 1986). Escherichia coli NM522 supE thi $\Delta$ (lac-pro $A B) \Delta b s d-5\left(\mathrm{r}^{-} \mathrm{m}^{-}\right)\left[\mathrm{F}^{\prime}\right.$ pro $A B$ lac $\left.I^{9} \mathrm{Z} \Delta \mathrm{M} 15\right]$ was used as a host strain for subcloning and analysis of sucrose-hydrolysing activity. E. coli $\mathrm{LE} 392 \mathrm{~F}^{-}$bsdR $574\left(\mathrm{r}_{\mathrm{k}}^{-} \mathrm{m}_{\mathrm{k}}^{+}\right)$supE44 supF 58 lac $Y 1$ or $\Delta($ lacIZY $6 \mathrm{galK} 2 \mathrm{galT} 22$ metB1 $\operatorname{trpR} 55$ was used to host the recombinant plasmid pAM2001, which contains a $4.5 \mathrm{~kb}$ insert 
of $B$. stearothermopbilus NUB36 DNA in pBR325. A minicellproducing strain of $E$. coli, DE3 end $A 1 \operatorname{rec} A 1$ gyr $A 96$ thi, bsd $17\left(\mathrm{r}_{\mathrm{k}}^{-} \mathrm{m}_{\mathrm{k}}^{+}\right) \operatorname{rel} A 1$ supE44 $\Delta($ lac-pro $A B)\left[\mathrm{F}^{\prime} \operatorname{traD} 36\right.$ pro $A B$ lac $\left.I^{\mathrm{a}} Z \Delta \mathrm{M} 15\right] \lambda(\mathrm{DE} 3)$, was used to study the expression of the cloned gene encoding the sucrose-hydrolysing enzyme. The cloning vectors pT7T3 (Pharmacia) and pGEM-7Zf $(+$ ) (Promega) were used to obtain nested deletions of inserted DNA. Ampicillin $\left(100 \mu \mathrm{g} \mathrm{ml}^{-1}\right)$ was used to maintain plasmids.

E. coli transformants were propagated on both Luria-Bertani (LB) medium (10 g polypeptone, $5 \mathrm{~g}$ yeast extract, and $5 \mathrm{~g} \mathrm{NaCl}$ $\left.\mathrm{l}^{-1}, \mathrm{pH} 7 \cdot 2\right)$ and EMB plates $(10 \mathrm{~g}$ bacto tryptone, $1 \mathrm{~g}$ yeast extract, $5 \mathrm{~g} \mathrm{NaCl}, 2 \mathrm{~g} \mathrm{K \textrm {K } _ { 2 }} \mathrm{PO}_{4}, 0.04 \%$ eosin $\mathrm{Y}, 0.0065 \%$ methylene blue, $1 \%$ sucrose and $15 \mathrm{~g}$ agar per litre).

Plasmid constructions and subcloning of the surA gene. Plasmid pAM2001 was isolated by E. Liong during construction of a gene bank of $B$. stearothermophilus NUB36 DNA in pBR325 (Liong, 1995). A $4.5 \mathrm{~kb} \mathrm{BamHI-SpbI-digested} \mathrm{fragment} \mathrm{from}$ pAM2001 was isolated and ligated to BamHI-SpbI-digested pT7T3 to produce pAM2002. The $4.7 \mathrm{~kb}$ HindIII-SacI fragment of pAM2002 (including some vector DNA) was subcloned into HindIII-SacI-digested pGEM-7Zf $(+)$ to create pAM2003. The ligation mixtures were transformed into $E$. coli NM522 using the standard competent-cells method (Maniatis et al., 1982), and transformants were selected on LB agar plates containing X-Gal and ampicillin $\left(100 \mu \mathrm{g} \mathrm{ml}^{-1}\right)$. Transformants containing the intact sur $A$ gene were identified on EMB plates containing $4 \%$ sucrose. The resultant plasmids, pAM2002 and pAM2003, which contained the $\operatorname{sur} A$ fragment in the two orientations relative to the vectors, were used to subclone and sequence the gene.

Progressive deletions of both orientations were generated by unidirectionally digesting SacI-BamHI-digested pAM2002 and AatII-HindIII-digested pAM2003 with exonuclease III (Promega). The end-points of the deletions were separated by about $200 \mathrm{bp}$. The fragments were ligated with T4 ligase and transformed into $E$. coli NM522, in which the plasmids were amplified and purified. The resulting constructs, whose insert end-points are shown in Fig. 1, served as the source of DNA for nucleotide sequencing and sucrase activity determinations.

In order to increase the yield of the sucrase expressed in $E$. coli, the $\operatorname{sur} A$ gene was subcloned into the high-expression vector pTrc99A (Pharmacia) by double-digesting pAM2008 with Ncol and SacI. The $2.45 \mathrm{~kb}$ digested DNA fragment was recovered and ligated with $\mathrm{NcoI}$ and SacI double-digested pTrc99A. The resultant clone, pAM2020, was chosen for further purification of sucrase (SurA protein).

DNA sequencing. Nucleotide sequences were determined by the dideoxy chain-termination method (Sanger et al., 1975) using plasmid DNA as the template, Taq DNA polymerase (Promega), and fluorescent-dye-coupled primers. The reaction products were analysed with a model ABI370A automated DNA sequencer (Applied Biosystems). Sequencing was performed for the entire length of both strands. The sequence data obtained were analysed using the Australian National Genomic Information Service (ANGIS) at Sydney University.

Expression of SurA. The E. coli strain DE3 was used to analyse the protein encoded by the recombinant plasmid. Purification of bacteria and $\mathrm{L}-\left[{ }^{35} \mathrm{~S}\right]$ methionine incorporation experiments were performed according to the method of Tabor \& Richardson (1985).

Cellular localization of sucrase in E. coli. Periplasmic and cytoplasmic cell fractions were prepared by the osmotic shock method (Kellermann \& Ferenci, 1982). Cell extract was prepared using the method described previously (Francis et al.,
1991). $\beta$-Galactosidase was assayed as a cytoplasmic marker, and $\beta$-lactamase as a periplasmic marker.

Purification of SurA. E. coli NM522 harbouring pAM2020 was grown overnight with shaking at $37{ }^{\circ} \mathrm{C}$ in $50 \mathrm{ml}$ nutrient broth supplemented with $0.4 \%$ sucrose and $100 \mu \mathrm{g}$ ampicillin $\mathrm{ml}^{-1}$. A $40 \mathrm{ml}$ volume of overnight culture was inoculated into 41 nutrient broth supplemented with $0.4 \%$ sucrose and $100 \mu \mathrm{g}$ ampicillin $\mathrm{ml}^{-1}$ and shaken at $37^{\circ} \mathrm{C}$ for about $3 \mathrm{~h}$ until the $\mathrm{OD}_{590}$ reached 0.5 . IPTG was added $(0.2 \mathrm{mM}$ final concentration) and shaking continued at $37^{\circ} \mathrm{C}$ for another $2.5 \mathrm{~h}$. Cells were harvested by centrifugation and washed with $400 \mathrm{ml}$ $20 \mathrm{mM}$ HEPES buffer ( $\mathrm{pH} 7 \cdot 5$ ), containing $1 \mathrm{mM}$ DTT. Bacteria were collected by centrifugation and resuspended in $50 \mathrm{ml} 20 \mathrm{mM}$ HEPES buffer ( $\mathrm{pH} 7 \cdot 5$ ), containing $1 \mathrm{mM}$ DT'T, $2 \mathrm{mM}$ PMSF and RNase/DNase mixture (each $1 \mathrm{mg} \mathrm{m}^{-1}$ final concentration). Bacteria were broken using a French press [12000 p.s.i. ( $82 \cdot 8 \mathrm{MPa})]$ and $\mathrm{MgSO}_{4}$ (1 mM final concentration) was added to the broken cells. The suspension was centrifuged (15 min, $4000 \mathrm{~g}$ ). The supernatant was collected and centrifuged ( $60 \mathrm{~min}, 48400 \mathrm{~g}$ ) for $1 \mathrm{~h}$ and the supernatant dialysed overnight against $3120 \mathrm{mM}$ HEPES buffer ( $\mathrm{pH} 7 \cdot 5)$, containing $1 \mathrm{mM}$ DTT.

The dialysed crude extract was loaded onto a $6.5 \times 2.5 \mathrm{~cm}$ affinity column prepared following the method of Ferenci \& Lee (1982), except that $50 \mathrm{mg}$ sucrose $\mathrm{ml}^{-1}$ was coupled to the oxirane-activated Sepharose. The affinity column was eluted with $35 \mathrm{ml} 20 \mathrm{mM}$ HEPES buffer ( $\mathrm{pH} \mathrm{7.5)}$ ) followed by $20 \mathrm{ml}$ $20 \mathrm{mM}$ HEPES buffer ( $\mathrm{pH} 7 \cdot 5$ ) containing $0 \cdot 1 \mathrm{M}$ glycine. Fractions containing sucrase activity were eluted between 40 and $55 \mathrm{ml}$; these were pooled and applied to a $2.5 \times 12 \mathrm{~cm}$ column of DEAE-Sephacel previously equilibrated with $20 \mathrm{mM}$ HEPES buffer ( $\mathrm{pH} 7.5$ ), containing $1 \mathrm{mM}$ DTT. A linear $400 \mathrm{ml}$ gradient of $80 \mathrm{mM}$ to $0.4 \mathrm{M} \mathrm{KCl}$ was applied over $15 \mathrm{~h}$ elution. Fractions (eluted after $230-350 \mathrm{ml}$ ) with high sucrase activity were combined and concentrated by freeze-drying. The concentrated sample was applied at a flow rate of $5.2 \mathrm{ml} \mathrm{h}^{-1}$ to a $1.5 \times 80 \mathrm{~cm}$ column of Sephacryl-300 (Pharmacia) equilibrated with $20 \mathrm{mM}$ HEPES buffer ( $\mathrm{pH} 7 \cdot 5$ ), containing $1 \mathrm{mM}$ DTT. Fractions eluted between 60 and $80 \mathrm{ml}$ containing sucrase activity were pooled and concentrated for further enzymic studies. A summary of the purification is shown in Table 1.

Sucrase assay. E. coli was grown at $37^{\circ} \mathrm{C}$ overnight in $10 \mathrm{ml}$ nutrient broth supplemented with $0.4 \%$ sucrose and $100 \mu \mathrm{g}$ ampicillin $\mathrm{ml}^{-1}$ and harvested by centrifugation. In assays of clones, the bacteria were washed twice with $100 \mathrm{mM}$ sodium phosphate buffer ( $\mathrm{pH} \mathrm{6.6)}$ ) and adjusted to $\mathrm{OD}_{490} 2 \cdot 0$. Then $20 \mu \mathrm{l}$ toluene was added to $1 \mathrm{ml}$ bacterial suspension followed by incubation at room temperature for $10 \mathrm{~min}$. Each $1 \mathrm{ml}$ decryptified cell suspension or broken cell extract then received $100 \mu \mathrm{l}$ $500 \mathrm{mM}$ sucrose followed by incubation for $30 \mathrm{~min}$ at $55^{\circ} \mathrm{C}$. The assay mixture was heated in a boiling water bath for $1 \mathrm{~min}$ to stop the reaction. The samples were centrifuged for $2 \mathrm{~min}$ and the supernatant was collected for determination of glucose concentrations. Glucose concentration was measured using the Sigma Glucose Trinder Reagent according to the manufacturer's instructions. Sucrase activity of toluene-treated bacteria was expressed as nmol glucose released $\min ^{-1}$ by $10^{8}$ bacteria at $55^{\circ} \mathrm{C}$. Sucrase activity in French press extracts and in fractions during purification was expressed as nmol glucose released $\mathrm{min}^{-1}$ (mg protein) $)^{-1}$ at $55^{\circ} \mathrm{C}$.

Sucrose-6-phosphate hydrolase assay. E. coli was grown at $37^{\circ} \mathrm{C}$ overnight in $100 \mathrm{ml}$ nutrient broth supplemented with $0.4 \%$ sucrose and $100 \mu \mathrm{g}$ ampicillin $\mathrm{ml}^{-1}$. The cultures were harvested by centrifugation $\left(10 \mathrm{~min}\right.$ at $4000 \mathrm{~g}$ at $\left.4{ }^{\circ} \mathrm{C}\right)$. The bacteria were washed with $100 \mathrm{ml} 10 \mathrm{mM}$ sodium phosphate 
buffer (pH 6.8) and resuspended in $10 \mathrm{ml} 10 \mathrm{mM}$ sodium phosphate buffer ( $\mathrm{pH} 6.8$ ) containing PMSF ( $2 \mathrm{mM}$ ), RNase and DNase (each at $1 \mathrm{mg} \mathrm{ml}^{-1}$ ). Bacteria were lysed by passing through a French press at 12000 p.s.i. and $1 \mathrm{mM} \mathrm{MgSO}$ was added. The mixture was centrifuged to remove unbroken bacteria and recentrifuged $\left(60 \mathrm{~min}\right.$ at $48400 \mathrm{~g}$ at $\left.4^{\circ} \mathrm{C}\right)$. The sucrose-6-phosphate hydrolase activity of the supernatant was assayed by measuring the release of glucose 6-phosphate after $30 \mathrm{~min}$ at $55^{\circ} \mathrm{C}$. Each $1 \mathrm{ml}$ reaction mix contained $100 \mathrm{mM}$ MES buffer $\mathrm{pH} 7 \cdot 1,1 \mathrm{mM}$ sucrose 6-phosphate (Sigma) and $100-200 \mu$ extract. The glucose 6-phosphate was measured in a spectrophotometric coupled assay in the presence of glucose-6phosphate dehydrogenase and NADP (Chassy \& Porter, 1979). Each $1 \mathrm{ml}$ reaction mix contained $100 \mathrm{mM}$ MES buffer $(\mathrm{pH} 7 \cdot 1)$, $0.5 \mathrm{mM}$ NADP, 3 units glucose-6-phosphate dehydrogenase and $100-200 \mu \mathrm{l}$ extract at $30^{\circ} \mathrm{C}$.

\section{RESULTS}

\section{Subcloning and localization of the sucrase gene (surA)}

Plasmid pAM2001 contained an insert of chromosomal DNA from B. stearothermophilus NUB36 and conferred on E. coli $\mathrm{K}-12$ the ability to utilize sucrose, as tested on fermentation indicator plates. The presence of the plasmid also permitted growth of $E$. coli on sucrose-minimal media. Assays of extracts indicated the presence of an additional sucrase activity in $E$. coli containing the pAM2001-derived plasmid pAM2003, as indicated in Fig. 1. Subclones of the $4.5 \mathrm{~kb}$ DNA insert and deletion derivatives generated using exonuclease III were used to identify the coding region for sucrose utilization. As also shown in Fig. 1, deletions from the left end of the clone decreased sucrose utilization, but sucrase activity was retained in a subclone containing only $2 \mathrm{~kb}$ of insert (pAM2008). In contrast, deletion of $0.2 \mathrm{~kb}$ from the right (DraI) side led to the complete loss of sucrose-hydrolysing activity. Therefore, the likely location of the sucrosehydrolysing enzyme was between the NdeI and DraI sites (Fig. 1).

\section{Nucleotide sequence of surA}

The nucleotide sequence of $\operatorname{sur} A$ was determined in the subclone (pAM2008) retaining sucrase activity (Fig. 1). The sequence (not shown; GenBank accession number U34872) indicated one open reading frame starting with an ATG codon at position 630 and ending with TAA codon at position 1965. This gene is composed of 1338 nucleotides and codes for a 445-amino-acid protein with a calculated $M_{\mathrm{r}}$ of 51519 . The $\mathrm{G}+\mathrm{C}$ content of the $\operatorname{sur} A$ gene was $41.8 \mathrm{~mol} \%$. The coding region of $\operatorname{sur} A$ is preceded by a putative translational start signal, .. GAGGGGGGAG .., 7 bp upstream of the start codon. No potential -35 and -10 consensus sequence was found upstream of the $\operatorname{sur} A$ gene, and a coding region is apparent before an intergene region of $152 \mathrm{bp}$. Another feature of the DNA sequence was an inverted repeat $\left(\Delta G-77 \mathrm{kcal} \mathrm{mol}^{-1} ;-322 \mathrm{~kJ} \mathrm{~mol}^{-1}\right)$ downstream from the $\operatorname{sur} A$ termination codon $(98 \mathrm{nt}$ after the $\operatorname{sur} A$ stop codon), which might act as a transcription terminator for the gene.

\section{Deduced amino acid sequence of SurA}

The deduced amino acid sequence of the $B$. stearothermophilus NUB36 sur $A$ gene product was compared with those of other related protein sequences (Fig. 2). The SurA protein exhibited significant amino acid identity to the sucrose-6-phosphate hydrolase (SacA) of $B$. subtilis (55.3\% identity in a 421 -amino-acid overlap) and to the sucrose-6-phosphate hydrolases (ScrB) of K. pneumoniae and Strep. mutans $(47.3 \%$ identity in a 357 -amino-acid overlap and $38.1 \%$ identity in a 181 -amino-acid overlap, respectively). SurA also showed a high level of identity to the sucrase (SacA) of Z. mobilis (36.8\% identity in a 418amino-acid overlap), the sucrase ( $\mathrm{ScrB}$ ) of $V$. alginolyticus (42.9\% identity in a 354-amino-acid overlap), the levanase (SacC) of B. subtilis (31\% identity in a 384-amino-acid

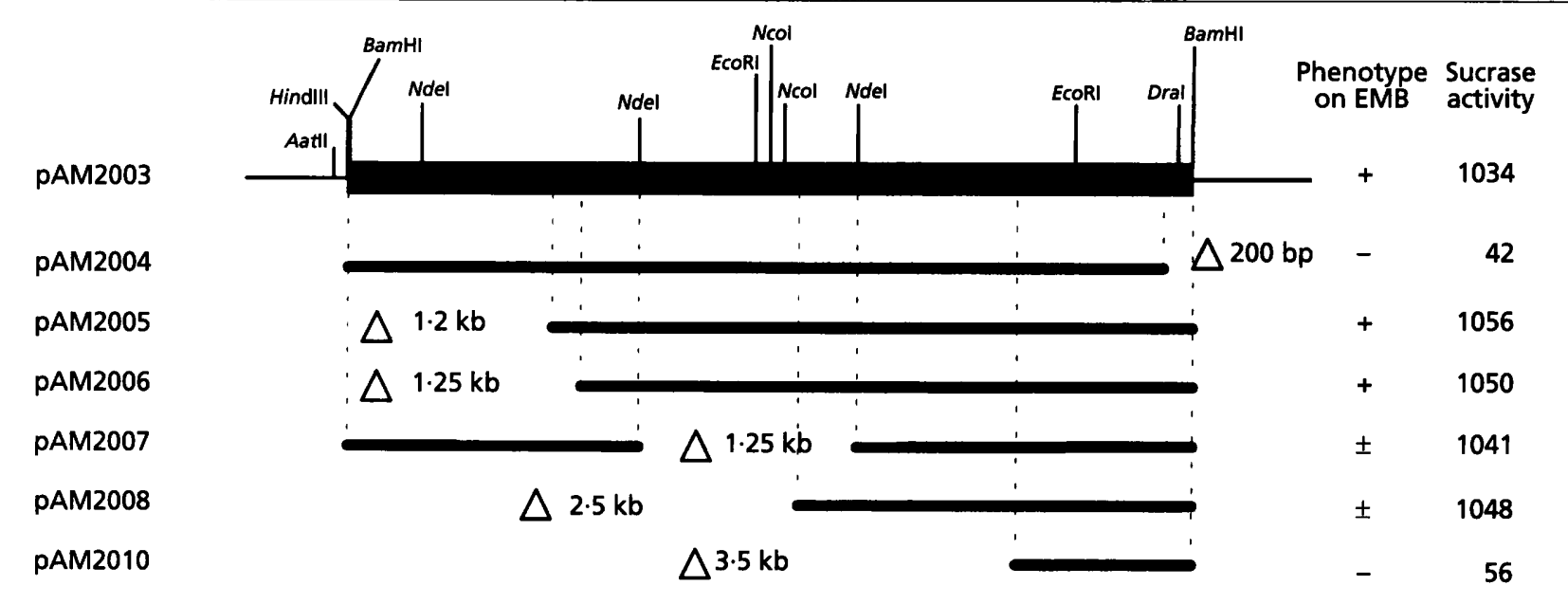

Fig. 1. Linear map of deletion derivatives of pAM2003. The cloned $4.5 \mathrm{~kb}$ DNA fragment of $B$. stearothermophilus NUB36 is shown in the black box. +, Positive fermentation phenotype on sucrose-EMB plates; -, lack of sucrose fermentation; \pm , partial positive phenotype. The sucrase activity of each clone ( $\mathrm{nmol}$ glucose released $\mathrm{min}^{-1}$ by $10^{8}$ bacteria) is also shown. 


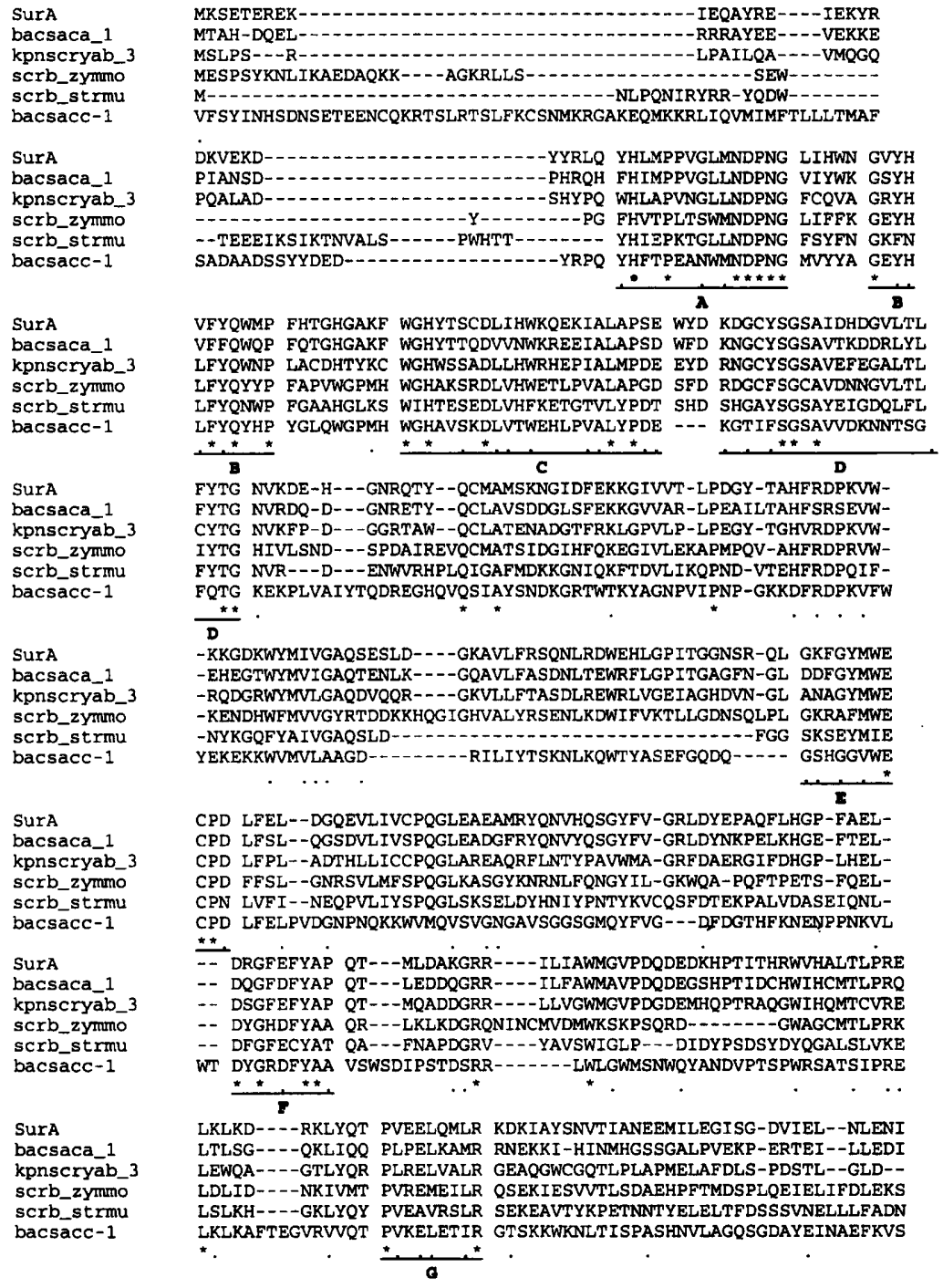

Fig. 2. Comparison of the deduced amino acid sequence of $B$. stearothermophilus NUB36 SurA with sucrose hydrolases from other organisms. The proteins compared are the products of the following genes: bacsaca_1, B. subtilis sacA gene encoding sucrose-6-phosphate hydrolase; kpnscryab_3, Klebsiella pneumoniae scrB gene encoding sucrase; scrb_zymmo, Zymomonas mobilis sacA gene; scrb_strmu, Streptococcus mutans scrB gene encoding sucrose 6-phosphate hydrolase; bacsacc-1, B. subtilis sacC gene encoding levanase. Asterisks indicate identity across all sequences; dots indicate conservative substitutions. The last 65 residues of SurA, less obviously alignable with the other proteins, are not shown. overlap) and Suc1, the yeast invertase (26.6\% identity in a 338-amino-acid overlap).

Alignment of the amino acid sequence of SurA with five published amino acid sequences of enzymes involved in sucrose hydrolysis revealed strong homology in seven areas (Fig. 2). The so called 'sucrose box' (area D) identified by Sato \& Kuramitsu (1988) and suggested to be important for enzymes catalysing the transfer of fructose from sucrose was conserved in all six aligned sequences. The amino acid sequence G-Y-M-W-E-C-P-D around cysteine 222 (area $\mathrm{E}$ ) in the sur $A$-encoded protein was also highly conserved in all the sequences. The importance of this region, as postulated by Martin et al. (1987), is that it may contain a catalytic thiol group. Five amino acid residues, N-D-P-N-G, in area $A$ were identical in all six sugar hydrolases, suggesting the importance of this region to sucrose hydrolytic activity. The amino acid residues were particularly conserved in the $\mathrm{NH}_{2}$-terminus of all the above compared enzymes (areas A-D), suggesting the importance of this region in the formation of the enzyme active site. The amino acid sequence of SurA and $B$. subtilis levansucrase show $<18 \%$ identity, as was the case $(<12 \%)$ between the B. subtilis sucrase and levansucrase (Fouet $e t$ al., 1986).

\section{Analysis of the products of surA in E. coli}

The $B$. stearothermophilus NUB36 sur $A$ gene was expressed in $E$. coli $\mathrm{DE} 3$ transformed by pAM2008 (containing sur $A$ only). After the incorporation of $\left[{ }^{35} \mathrm{~S}\right]$ methionine, the protein bands were analysed by SDS-PAGE and autoradiograghy. One major protein band of $M_{\mathrm{r}}$ around 57000 was observed (Fig. 3). This value agrees reasonably with that (51519) deduced from the nucleotide sequence of $\operatorname{sur} A$. No other major products were seen, even with the full-length $(4.5 \mathrm{~kb})$ clone.

\section{Localization and characterization of SurA expressed in E. coli}

Most $(90 \%)$ of the sucrase activity in E. coli NM522 harbouring pAM2008 was recovered in the soluble cell fraction (cytoplasm and periplasm); no sucrase activity was found in the culture supernatant. To further identify the distribution of the sucrase (SurA) between cytoplasm 


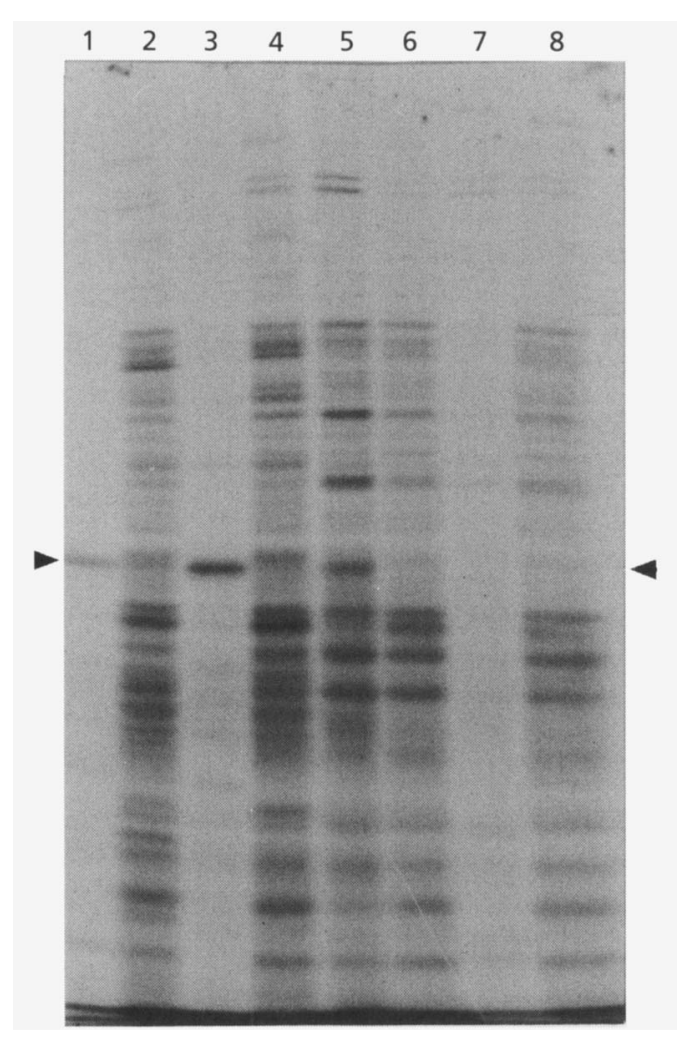

Fig. 3. Expression of the SurA protein in E. coli. The figure shows an autoradiograph of SDS-PAGE analysis of the $\left[{ }^{35} \mathrm{~S}\right] m$ ethionine-labelled proteins extracted from $E$. coli DE3 harbouring the following plasmids: lanes 1 and 2, pAM2003 (containing the entire cloned $4.5 \mathrm{~kb}$ DNA fragment); lanes 3 and 4, pAM2006 (containing $3.25 \mathrm{~kb}$ of the cloned $4.5 \mathrm{~kb}$ fragment; see Fig. 1); lanes 5 and 6, pAM2008 (containing close to $2 \mathrm{~kb}$ of the cloned $4.5 \mathrm{~kb}$ fragment; see Fig. 1); lanes 7 and 8, the cloning vector pGEM-7Zf(+). Odd-numbered lanes, IPTGinduced cells; even-numbered lanes, uninduced cells. The arrowheads point to the band migrating at $M_{r} \mathbf{5 7 0 0 0}$ present in all sucrase-expressing clones.

and periplasm, osmotic shock analyses were carried out. In two experiments, $64-80 \%$ of the total sucrosehydrolysing activity was retained in the cytoplasm and 9-19\% was recovered from the osmotic shock fluid, which suggested that the E. coli-expressed SurA was a soluble, cytoplasmic protein. Indeed, the distribution of sucrase was closer to the cytoplasmic marker enzyme $\beta$ galactosidase (88-92\% in the cytoplasm) than the periplasmic marker $\beta$-lactamase (11-17\% in the cytoplasm) in the same fractionation.

\section{Partial purification of SurA}

To improve the yield of SurA for purification, $\operatorname{sur} A$ was subcloned into the high-expression vector pTrc99A, resulting in clone pAM2020. Comparison of the sucrosehydrolysing activity of E. coli JM105 harbouring pAM2008, pAM2006 or pAM2020 showed that about five times greater activity was achieved by subcloning the sur $A$ into pTrc99A. The sucrose hydrolase (SurA) was partially purified after sucrose affinity chromatography, DEAE-anion-exchange and gel-filtration chromatography. Overall, sucrose hydrolase was purified approximately 22 -fold, with a recovery of $26 \%$ (Table 1 ). The protein was not entirely pure, as four other minor bands were present in the preparation analysed by SDS-PAGE (not shown).

\section{Properties of the expressed SurA}

The optimum temperature for the activity of the sucrase was determined by incubating the partially purified enzyme with sucrose in phosphate buffer at different temperatures. Activity was maximal at $55^{\circ} \mathrm{C}$, but rapidly dropped to one-quarter of this activity at $60^{\circ} \mathrm{C}$. Almost no sucrose-hydrolysing activity was detected at $70^{\circ} \mathrm{C}$, which is above the $65^{\circ} \mathrm{C}$ growth optimum of the organism (Fig. 4a).

The stability of the sucrase at different temperatures was tested by incubating the partially purified enzyme at 55,60 and $70^{\circ} \mathrm{C}$, and assaying samples taken at different time points for sucrose-hydrolysing activity. The sucrase was stable at $55^{\circ} \mathrm{C}$ for at least $1 \mathrm{~h}$ but gradually lost activity at $60^{\circ} \mathrm{C}$. The enzyme activity dropped to almost zero after $5 \mathrm{~min}$ at $70^{\circ} \mathrm{C}$ (Fig. $4 \mathrm{~b}$ ). The enzyme was very stable at room temperature (enzyme activity remained the same after $3 \mathrm{~d}$ at room temperature).

The activity and affinity of the $B$. stearothermophilus sucrase for sucrose and sucrose 6-phosphate were studied using the partially purified enzyme. Using a sucrose concentration range from 1 to $200 \mathrm{mM}$, the rates of sucrose hydrolysis were measured by calculating the rate of glucose released from the slopes of the initial velocity curves. The apparent $K_{\mathrm{m}}$ value of the sucrase was found to be $40 \mathrm{mM}$ from a linear double-reciprocal plot.

As sucrase activity is associated with a sucrose-6-phosphate hydrolase in B. subtilis (Kunst et al., 1974), this second activity was also assayed, using two different methods (Chassy \& Porter, 1979; St Martin \& Wittenberger, 1979). Despite strong sucrose-hydrolysing activity being detected in the cell extract of E. coli NM522 harbouring pAM2008, no cleavage of sucrose 6-phosphate to glucose 6-phosphate was detected. This was surprising considering the strong sequence homology with the sucrose-6-phosphate hydrolases mentioned above, and it is possible that SurA may have the ability to hydrolyse sucrose 6-phosphate under assay conditions not tested by us.

The $M_{\mathrm{r}}$ of the native form of sucrase (SurA) was determined using gel-filtration chromatography (Sephacryl 300) and calibration with standard markers [thyroglobulin (670000), bovine gamma globulin (158000), chicken ovalbumin (44000), equine myoglobin (17000) and vitamin $\left.\mathrm{B}_{12}(1350)\right]$. An $M_{\mathrm{r}}$ of 105000 was calculated from a linear calibration curve. The $M_{\mathrm{r}}$ of SurA of B. stearothermophilus deduced from the DNA sequence was 51519 , so, the native form of the enzyme is probably a dimer. 
Table 1. Partial purification of the cloned B. stearothermophilus NUB36 sucrase from $E$. coli extracts

Sucrase was assayed in the extract and subsequent column fractions as described in Methods. The conditions for sucrose-Sepharose affinity chromatography, ion-exchange chromatography and gel filtration are also defined in Methods.

\begin{tabular}{|lcccc|}
\hline Step & $\begin{array}{c}\text { Total } \\
\text { activity } \\
\text { (units) }\end{array}$ & $\begin{array}{c}\text { Total protein } \\
\text { (mg) }\end{array}$ & $\begin{array}{c}\text { Specific } \\
\text { activity } \\
\text { (units } \mathbf{~ m g}^{-\mathbf{1}} \text { ) }\end{array}$ & $\begin{array}{c}\text { Recovery } \\
\text { (\%) }\end{array}$ \\
\hline Crude extract & 1193 & 260 & $4 \cdot 6$ & 100 \\
Affinity chromatography & 462 & 21 & 22 & 39 \\
DEAE-Sephacel & 384 & $5 \cdot 8$ & 66.8 & 32 \\
chromatography & 312 & 3.0 & 103 & 26 \\
$\begin{array}{l}\text { Sephacryl-300 } \\
\text { chromatography }\end{array}$ & & & & \\
\hline
\end{tabular}

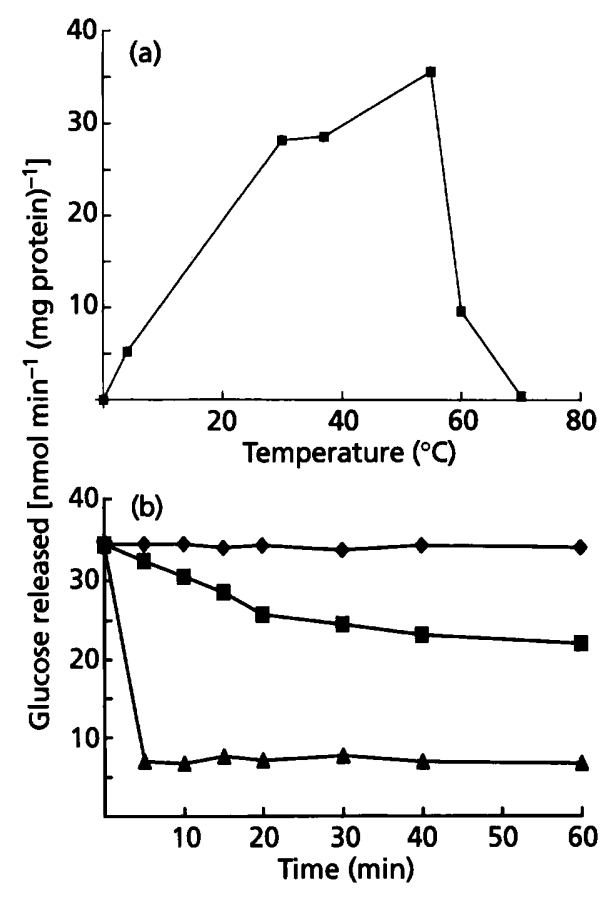

Fig. 4. (a) Temperature-activity profile for the partially purified $B$. stearothermophilus NUB36 sucrase. (b) Stability of the sucrase at $55^{\circ} \mathrm{C}(\diamond), 60^{\circ} \mathrm{C}(\square)$ and $70^{\circ} \mathrm{C}(\Delta)$.

\section{DISCUSSION}

Comparison of the amino acid sequence of the $\operatorname{sur} A$ encoded protein with other functionally similar proteins showed that it shares $55 \cdot 3 \%, 38 \cdot 1 \%$ and $47 \cdot 3 \%$ amino acid identity with the sucrose-6-phosphate hydrolases of B. subtilis (SacA), Strep. mutans (ScrB) and K. pneumoniae (ScrB), respectively. Amino acid identities of $42.9 \%$ and $36.8 \%$ were found by comparison with the sucrases of $V$. alginolyticus ( $\mathrm{ScrB}$ ) and $Z$. mobilis ( $\mathrm{Sac} A)$, respectively. Further sequence analysis showed that the sucrose box, a consensus sequence containing nine amino acids (Sato \&
Kuramitsu, 1988) was conserved in B. stearothermopbilus NUB36 sucrase. This result supports the suggestion (Sato \& Kuramitsu, 1988) that the sucrose box is important for enzymes catalysing the hydrolysis of sucrose into glucose and fructose.

The strong homology with both sucrose-6-phosphate hydrolases and sucrases suggested that the sur $A$-encoded protein of $B$. stearothermophilus NUB36 would be able to hydrolyse both sucrose 6-phosphate and sucrose, with different affinities, as does the scrB-encoded sucrose-6phosphate hydrolase of Strep. mutans expressed in E. coli, which showed a $K_{\mathrm{m}}$ of $180 \mathrm{mM}$ for sucrose and $0.08 \mathrm{mM}$ for sucrose 6-phosphate (Lunsford \& Macrina, 1986). However, the partially purified B. stearothermophilus SurA demonstrated an apparent $K_{\mathrm{m}}$ of $40 \mathrm{mM}$ for sucrose but no sucrose 6-phosphate hydrolase activity was observed.

Sequence analysis showed that the $\operatorname{sur} A$-encoded sucrase had no secretory signal sequence, and further experiments indicated that the E. coli-expressed SurA was located in the cytoplasmic fraction of the cell extract. This suggests that the enzyme is not secreted and that the substrate has to be accumulated in the cytoplasm by one or more sucrose transport systems. It is likely that the truncated open reading frame upstream of $\operatorname{sur} A$ is involved in sucrose transport, as deletion of this upstream region reduced sucrose fermentation (Fig. 1). The sequence of the upstream gene (submitted to GenBank with accession number U34873) resembled the sucrose enzyme II of $B$. subtilis (SacP), and the absence of a promoter in front of $\operatorname{sur} A$ makes it likely that $\operatorname{sur} A$ is coregulated with the upstream gene(s). In $B$. subtilis, the sacP sucrose phosphotransferase gene is upstream of the $\operatorname{sur} A$ homologue $(\operatorname{sac} A)$ but it remains to be shown whether there is a functional sucrose enzyme II present in B. stearothermophilus. It appears paradoxical that SurA operates in sucrose hydrolysis but not in sucrose phosphate cleavage, given that the gene sequence and gene organization resemble those responsible for sucrosephosphotransferase-mediated metabolism in B. subtilis. 
The optimum temperature for the activity of SurA was $55^{\circ} \mathrm{C}$ and the enzyme was highly stable at room temperature. The stability of SurA resembles that of the Strep. mutans sucrose-6-phosphate hydrolase, which was stable for several days at room temperature (Chassy \& Porter, 1979). The $M_{\mathrm{r}}$ of the SurA (expressed and partially purified from $E$. coli) determined by gel filtration was 105000 , indicating that the active form of the enzyme is probably a dimer. The $M_{\mathrm{r}}$ of $B$. subtilis SacA determined by chromatography was 40000 (Pascal et al., 1971), and to our knowledge no report about the dimerization of sucrose-hydrolytic enzymes has previously been published. The availability of the cloned $\operatorname{sur} A$ gene will permit more detailed future characterization of a thermophilic sucrase.

\section{ACKNOWLEDGEMENTS}

We thank Dr N. Welker for the NUB36 strain, and Eleanore Liong for the gift of pAM2001 and for communicating data prior to publication.

\section{REFERENCES}

Chassy, B. M. \& Porter, E. V. (1979). Initial characterization of sucrose 6-phosphate hydrolase from Streptococcus mutans and its apparent identity with intracellular invertase. Biochem Biophys Res Commun 89, 307-314.

Chen, Z. F., Wojcik, S. F. \& Welker, N. E. (1986). Genetic analysis of Bacillus stearothermophilus by protoplast fusion. J Bacteriol 165, 994-1001.

Ebner, R. \& Lengeler, J. W. (1988). DNA sequence of the gene $\operatorname{scr} A$ encoding the sucrose transport protein Enzymell ${ }^{\text {scr }}$ of the phosphotransferase system from enteric bacteria: homology of the

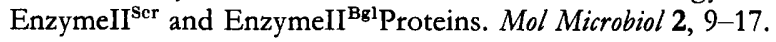

Ferenci, T. \& Lee, K. S. (1982). Directed evolution of the lambda receptor of Escherichia coli through affinity chromatographic selection. J Mol Biol 160, 431-444.

Fouet, A., Klier, A. \& Rapoport, G. (1986). Nucleotide sequence of the sucrase gene of Bacillus subtilis. Gene 45, 221-225.

Francis, G., Brennan, L. \& Ferenci, T. (1991). Affinitychromatographic purification of sixteen cysteine-substituted maltoporin variants: thiol reactivity and cross-linking in an outer membrane protein of Escherichia coli. Biochim Biophys Acta 1067, 89-96.

Gunasekaran, P., Karunakaran, T., Cami, B., Mukundan, A. G., Preziosi, L. \& Baratti, J. (1990). Cloning and sequencing of the sac $A$ gene: characterization of a sucrase from Zymomonas mobilis. $J$ Bacteriol 172, 6727-6735.

Kellermann, O. K. \& Ferenci, T. (1982). Maltose-binding protein from Escherichia coli. Methods Enzymol 90, 459-463.

Kunst, F., Pascal, M., Lepesant, J. A., Walle, J. \& Dedonder, R. (1974). Purification and some properties of an endocellular sucrase from a constitutive mutant of Bacillus subtilis Marburg 168. Eur J Biocbem 42, 611-620.
Lepesant, J. A. (1976). Specific and pleiotropic regulatory mechanisms in the sucrose system of Bacillus subtilis 168. In Microbiology - 1976, pp. 58-69. Edited by D. Schlessinger. Washington, DC: American Society for Microbiology.

Liong, E. C. (1995). Maltose genes in Bacillus stearothermophilus ATCC7953. PhD thesis, University of Sydney.

Lunsford, R. D. \& Macrina, F. L. (1986). Molecular cloning and characterization of $\operatorname{scr} B$ : the structural gene for the Streptococcus mutans PTS sucrose 6-phosphate hydrolase. J Bacteriol 166, 426-434.

Maniatis, T., Fritsch, E. F. \& Sambrook, J. (1982). Molecular Cloning: a Laboratory Manual. Cold Spring Harbor, NY: Cold Spring Harbor Laboratory.

Martin, I., Debarbouille, M., Ferranri, E., Klier, A. \& Rapoport, G. (1987). Characterisation of the levanase gene of Bacillus subtilis which shows homology to yeast invertase. Mol Gen Genet 208, 177-184.

Pascal, M., Kunst, F., Lepesant, J. A. \& Dedonder, R. (1971). Characterisation of two sucrase activities in Bacillus subtilis Marburg. Biochimie 53, 1059-1066.

Robeson, J. P., Barletta, R. G. \& Curtiss, R. (1983). Expression of a Streptococcus mutans glucosyltransferase gene in Escherichia coli. $J$ Bacteriol 153, 211-221.

Russell, R. R. B., Morrissey, P. \& Dougan, G. (1985). Cloning a sucrase gene from Streptococcus mutans in bacteriophage lambda. FEMS Microbiol Lett 30, 37-41.

St Martin, E. J. \& Wittenberger, C. L. (1979). Regulation and function of sucrose 6-phosphate hydrolase in Streptococcus mutans. Infect Immun 26, 487-491.

Sanger, F., Nicklen, S. \& Coulson, A. R. (1975). DNA sequencing with chain-terminating inhibitors. Proc Natl Acad Sci USA 74, 5463-5467.

Sato, Y. \& Kuramitsu, H. K. (1988). Sequence analysis of the Streptococcus mutans scrB gene. Infect Immun 56, 1956-1960.

Schmid, K., Schupfner, M. \& Schmitt, R. (1982). Plasmid-mediated uptake and metabolism of sucrose by Escherichia coli K12. J Bacteriol 151, 68-76.

Schmid, K., Ebner, R., Altenbuchner, J., Schmitt, R. \& Lengeler, J. W. (1988). Plasmid-mediated sucrose metabolism in Escherichia coli K12: mapping of the scr genes of PUR400. Mol Microbiol 2, 1-8.

Scholle, R. R., Robb, S. M., Robb, F. T. \& Woods, D. R. (1989). Nucleotide sequence and analysis of the Vibrio alginolyticus sucrose gene (scrB). Gene 80, 49-56.

Sharp, R. J., Bown, K. J. \& Atkinson, T. (1980). Phenotypic and genotypic characterisation of some thermophilic species of Bacillus. J Gen Microbiol 117, 201-210.

Tabor, S. \& Richardson, C. (1985). A bacteriophage T7 RNA polymerase promoter system for controlled exclusive expression of specific genes. Proc Natl Acad Sci US A 82, 1074-1078.

Welker, N. E. (1978). Physiological and genetic factors affecting transfection and transformation in Bacillus stearotbermophilus. In Biochemistry of Thermophily, pp. 127-147. Edited by S. M. Friendman. New York: Academic Press.

Received 12 December 1995; revised 21 February 1996; accepted 4 March 1996. 